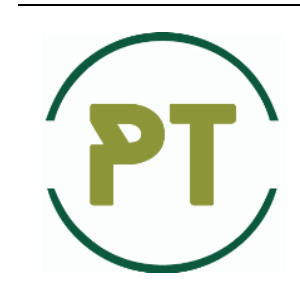

Problems of Tribology

Website: http://tribology.khnu.km.ua/index.php/ProbTrib

E-mail: tribosenator@gmail.com

DOI: https://doi.org/10.31891/2079-1372-2020-95-1-26-33

\title{
Determination of wear resistance and wear mechanisms of HVAF coatings based on Ni-Al composition depending on the technological modes of their deposition
}

\author{
A.G. Dovhal, L.B. Pryimak, I.L. Trofimov* \\ National Aviation University, Ukraine \\ *E-mail: troffi@ukr.net
}

\begin{abstract}
Presented studies are related to the spheres of aviation and machine-building. World aviation technology experience has accumulated a huge amount of statistical material on the failure airborne systems and ground equipment due to the increased level of parts wear. That is why the issue of research and improvement of antiwear properties aeronautical parts is one the components when considering the priority directions of ensuring the reliability of operation motor vehicles and friction units. The $\mathrm{Ni}_{3} \mathrm{Al}$ coating has been deposited on the medium carbon steel using high velocity air fuel deposition. It has been established that it is very sensible for modes of coating deposition and different chemical phenomenon have been detected. The structure of the obtained coating has been thoroughly researched on the electronic microscope. The obtained coating has been tested on the friction bench modeling the fretting process that is taking place in the couple of locking devices of self-propelled passengers stairs. The coating has also corrosion protection. The friction surfaces have been investigated on the electronic microscope and the wear mechanisms have been established. The optimal modes of the HVAF coting deposition from the viewpoint of wear resistance have been detected.
\end{abstract}

Key words: wear, wear resistance, coating, adhesion, coating deposition, high velocity air fuel (HVAF) deposition.

\section{Introduction}

One of the important problems of modern technological processes at airports is the technological, safe and efficient operation of aviation ground equipment used for ground handling of aircrafts. The reliability of ground handling technology directly affects not only the quality and intime of groundhandling, but also the reliability of the aircraft and the safety of the next flight as a whole [1]. The reliability and durability of the aircraft ground support equipment often refers to the durability and surface strength of its nodes and units [2]. This is determined by the strength and resource of ground support equipment, the resource and safety of which are generally determined by the efficiency of triboelements, which can be substantially improved by technological measures of surface hardening, in particular the application of protective coatings.

The main problems of operating the self-propelled passenger stairs of the ABS 580 series TLD, include especially the arrangement and operation of their operating body, namely the two-section staircase. The stair's special equipment is two sections of steps: a fixed section, the slope which is controlled by hydraulic cylinders (Fig. 1, a) and a movable sliding section, which moves along a fixed one and is fixed at the desired height by means of locking latches (Fig. 1, b).

The locking latch consists of a drive mechanism and a retractable tooth, which is usually made of hardened steel alloy. The retractable tooth of the locking latch goes into the corresponding hook welded to the frame of the retractable section that is usually made of structural steel and welded to the base at a distance of one step.

The total unloaded mass of the self-propelled passenger stairs is 4.7 tons. The operating temperature of the stairs is from $-20^{\circ} \mathrm{C}$ to $+45^{\circ} \mathrm{C}$.

The maximum number of passengers on the stairway is 74 people (equivalent to $5920 \mathrm{~kg}$ ). Maximum number of passengers on the platform is 7 (equivalent to $600 \mathrm{~kg}$ ). The maximum number of passengers in the upper section is possible 41(Fig. 1). 
The locking latches work in extremely difficult conditions. The pressure on the contact areas of teeth and hooks ranges from 10 to $250 \mathrm{MPa}$, depending on the extension of the section from the upper hooks to the lower ones, when the sections are pulled and loaded, including the weight of the section and the mass of passengers. from 8 to 41 people.

The process of friction in the couple of teeth of the locking latches and hooks of the sliding section corresponds to the fretting wear with the elements of the corrosion process if the paint coatings are being destroyed.

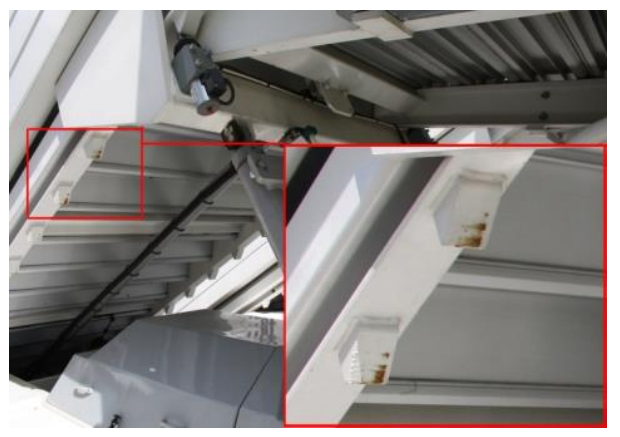

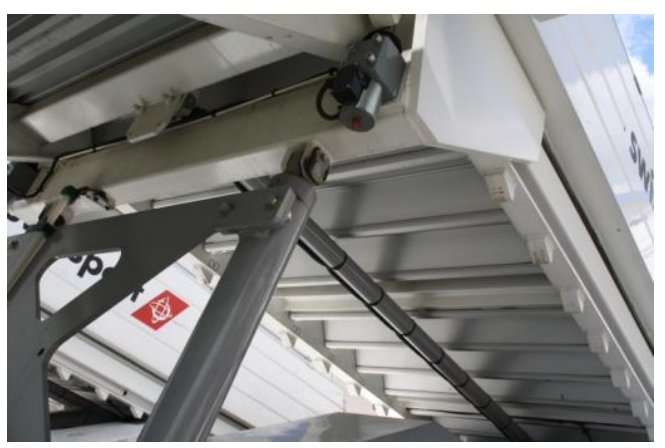

Fig. 1. The result of excessive wear of the supporting teeth in the locking section of the self-propelled passenger stairs ABS 580 firm TLD: a - wear of the right side; b - wear of the left side

The oscillation amplitudes are not predicted and depend on the wear of the coupling pair. The frequencies are of two types: low frequencies, which have no regular frequency and are extremely rare, and the fundamental oscillation frequency of the friction pair is the forced frequency from the rotation of the engine of the special machine at the rated mode of operation, which is $1600-1800 \mathrm{rpm}$, and corresponds to the oscillation frequency in $30 \mathrm{~Hz}$.

The loaded area of the contact tooth can be protected by a coating of a composition based on nickelaluminum intermetallide, which is well established as a protective composition.

\section{Review of the latest research}

When dissolving the aluminium in the nickel up to the concentration of $15 \%$ the strict stoichiometric compound $\mathrm{Ni}_{3} \mathrm{Al}$ is created. It has a number of useful properties for coating and metal ceramic materials.

So the contact interaction of the $\mathrm{Ni}_{3} \mathrm{Al}$ melt with the $\mathrm{SiC}-\mathrm{Al}_{2} \mathrm{O}_{3}$ has been investigated $[3,4]$ and it has been established that the chemical activity is reduced only keeping the stoichiometric compound $\mathrm{Ni}_{3} \mathrm{Al}$ and ceramic impregnation is saved.

The nickel-aluminium alloy is also useful not only for carbides and as well as for borides of titanium and cromium $[5,6]$ and initial structure is well kept for engineering application.

Basing on the previous research the wear proof and high-dense composition and coating have been obtained on the basis of diboride of titanium [7].

The infinitive dissolution of the nickel in the iron allows applying the Ni3Al as the sublayer for the ceramic coating and the metal matrix for ceramic impregnation. Thus the contact interaction of the Ni-Al alloys with the wear proof and thermal barrier composition $\mathrm{Al}_{2} \mathrm{O}_{3}-\mathrm{ZrO}_{2}$ has been investigated [8] and the creation of double eutectic of $\left(\mathrm{Al}_{2} \mathrm{O}_{3}-\mathrm{ZrO}_{2}\right)$ and $\left(\mathrm{Al}_{2} \mathrm{O}_{3}-\mathrm{Ni}_{3} \mathrm{Al}\right)$ under the interaction temperatures $1510^{\circ} \mathrm{C}$ has been detected, which is very useful for coatings depositions by high concentration energy techniques.

So, using the previous phenomenon the modes of HVAF coating have been detected and damage free coating has been obtained [9]. The high velocity air fuel deposition has a number of advantages for deposition of different compositions. It has less dynamic action on the powder and substrate as the detonation deposition has. And it has less temperature destruction on the powder batch mixture as the plasma deposition has. Using the HVAF deposition the coating is deposited in the supersonic stream of air-kerosene blast [10].

The $\mathrm{Ni}_{3} \mathrm{Al}$ alloy has been positively tested as the sublayer for plasma deposition coatings for the friction under the elevated temperatures.

So, taking into account all the mentioned application of the pure $\mathrm{Ni}_{3} \mathrm{Al}$ for protection of steel elements is of a great scientific interest.

Research aim

The aim of the research is to establish the optimal modes of the HVAF coating deposition from the viewpoint of the coating structure and properties.

\section{Research methodology}

In order to study the structure and durability of the HVAF-coatings we used original samples of structural steels of which the hooks of the upper section of the self-propelled stairs are made: Steel 45 (GOST 380 - 
2005) for the manufacture of cylinders $(20 \times 25)$ compatible for testing on a MFC-1 friction machine (Fig. 2), and a counterface made of HVG steel (GOST 5950-2000).

In order to obtain the charging metal for the coating we used intermetallide PNU 15 (GOST 21448 75) with an average size of 45 - 55 microns.

The equipment for coating by the method of high-speed air-fuel spraying. Nowadays, the technology of high-speed air-fuel spraying (HVAF) wear-resistant coatings is widely used in various industries for powder compositions. This method differs from the detonation one by smoothness and continuity of the coating process, and hence the insignificant dynamic effects on the unit, and from the plasma method - by the lower temperature influence on the unit and powder composition and the relatively low cost of the equipment.

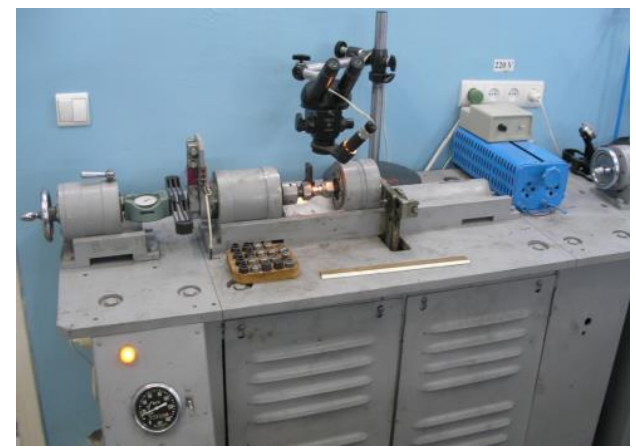

Fig. 2. General view of the operating unit of the friction machine MFC-1

The coatings were applied by the method of HVAF burner "Grad - B" on the universal thermosetting testing bench (UTTB).

Dependence of wear resistance and mechanisms of HVAF coatings wear on technological modes of their application

As the composite HVAF-coatings were intended to work as protection of teeth of locking latches of two-section passenger stairs, the modes of tribotechnical tests were chosen to model the operating conditions of a couple of locking latch-tooth of the sliding section. Namely, at vibrational frequencies of $30 \mathrm{~Hz}$, which corresponds to the average frequencies of rotation of the base engine when rotating the crankshaft $1800 \mathrm{rpm}$ in accordance with the rated operating mode of the internal combustion engine and loads at $1500 \mathrm{~N}$, which corresponds to the load on the friction contact area of $30 \mathrm{MPa}$, as it is exactly maximum amount of pressure on the contact section of the system "locking-tooth section" in the most unfavorable position, when the extended section of the hinge extended to the maximum length, the amplitude was $10 \mathrm{mkm}$, the test base composition $5 \times 10^{5}$ cycles - these indicators remained constant and the same for all test series coatings obtained at different technological modes of application and the remaining factors varied for optimization purposes of technological solutions.

Tribotechnical tests have been conducted according to the schedule "plane-plane" on a modified friction machine MFC-1, which allows to measure the average value of the friction coefficient (Fig. 2). Steel 40X9C2 (HRC 75 - 80) was selected as the counterface material. Two types of modes have been analyzed: at the constant flow of the fuel-air mixture the effect of the powder flow have been studied, and at the constant flow of the powder, the effect of changing the flow of the fuel-air mixture on the intensity of wear and friction coefficients, respectively.

In order to study the influence of these factors, coatings have been obtained with the change of these factors at three levels (Tab. 1) and technological features of the formation of these coatings have been determined. The results of tribotechnical tests of HVAF coatings at changes in the main technological wind resistance of the selected powder when it is possible to obtain a supersonic flow in the nozzle of the Grad-M burner, have been obtained. Thus, the ranking selected two main factors that significantly affect the structure of the coating, and, consequently, its durability, such as the flow rate of the fuel-and-air mixture and the powder consumption from the feeder of the assembly (Tab. 1).

Factors that significantly affect the structure of the coating

Table 1

\begin{tabular}{|c|c|c|c|}
\hline Fuel mixture consumption, g/s & Powder consumption, g/s & Protective atmosphere & Residual porosity, $\%$ \\
\hline 20 & 2,0 & --- & 7 \\
\hline 30 & 2,25 & --- & $1-2$ \\
\hline 40 & 2,5 & --- & 3 \\
\hline
\end{tabular}


Therefore, samples with appropriate coatings have been obtained in different modes and their wear resistance has been investigated (Fg. 3, 4).

Thus, the fuel-air mixture consumption affects the wear resistance as follows. For fuel-air mixture costs of $30 \mathrm{~g} / \mathrm{s}$ for all costs as follows. At the expense of the fuel-air mixture at $30 \mathrm{~g} / \mathrm{s}$ for all powder consumption, a minimum of wear was observed for the powder consumption of $2.25 \mathrm{~g} / \mathrm{s}$, the wear rate of the composition was 5 mkm. The friction coefficients at the HVAF-coatings, depending on the flow rate of the fuel-air mixture varies from 0.43 to 0.53 . This coating refers to the friction type, but it is intended for stabilization, not for heavy motion. For powder consumption of $30 \mathrm{~g} / \mathrm{s}$, the friction coefficients have a minimum for powder consumption of 2.5 $\mathrm{g} / \mathrm{s}$, the friction coefficient is 0.43 . It means that at low consumption of powder there is an increased porosity of coatings, and at high consumption there is thermal ignition of the intermetallic composition, so there is an intermediate optimum.

The increase in the powder flow rate from the feeder of the plant also significantly affects the tribotechnical characteristics of the obtained coatings (Fig. 4). Therefore, with increasing powder consumption, the wear rate exceeds at least the value of the powder consumption of $2.25 \mathrm{~g} / \mathrm{s}$, from 5 to 21 microns.

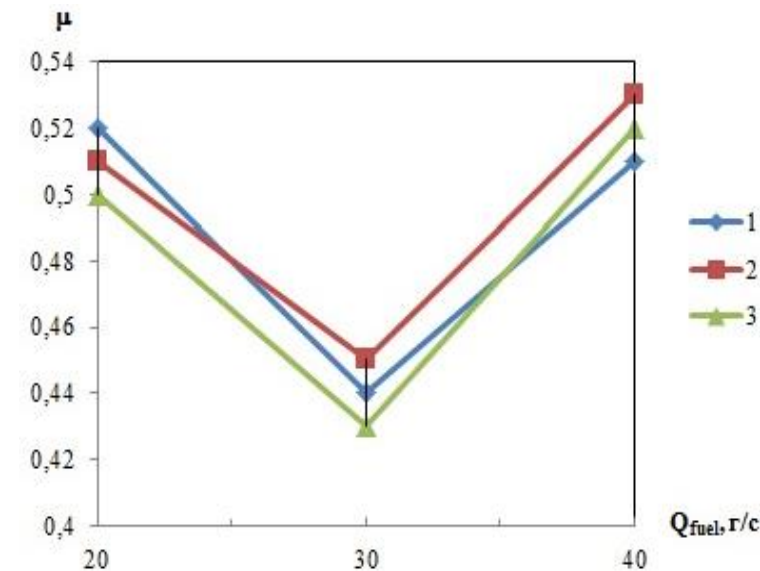

a

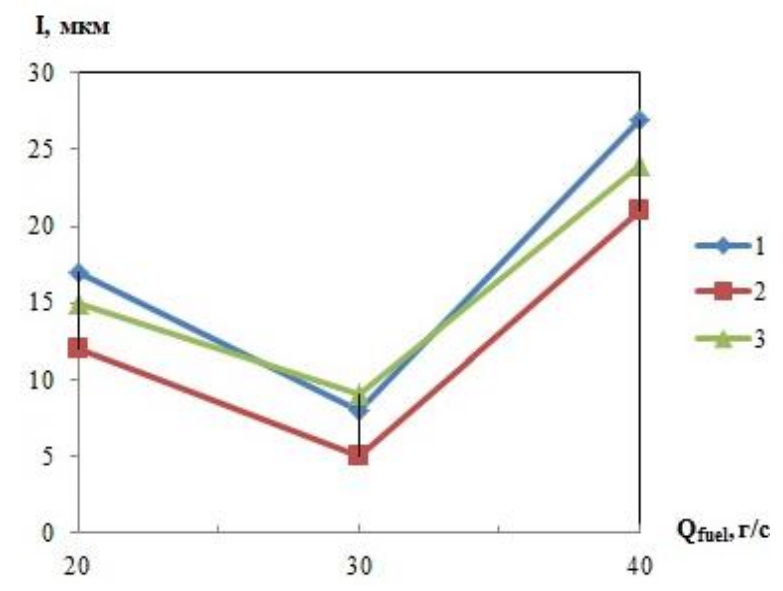

b

Fig. 3. Dependence of the wear rate (a) and the friction coefficient (b) on the consumption for different powder in the HVAF flow:

$$
\begin{gathered}
1-2 \mathrm{~g} / \mathrm{s} ; \\
2-2.25 \mathrm{~g} / \mathrm{s} ; \\
3-2.5 \mathrm{~g} / \mathrm{s}
\end{gathered}
$$

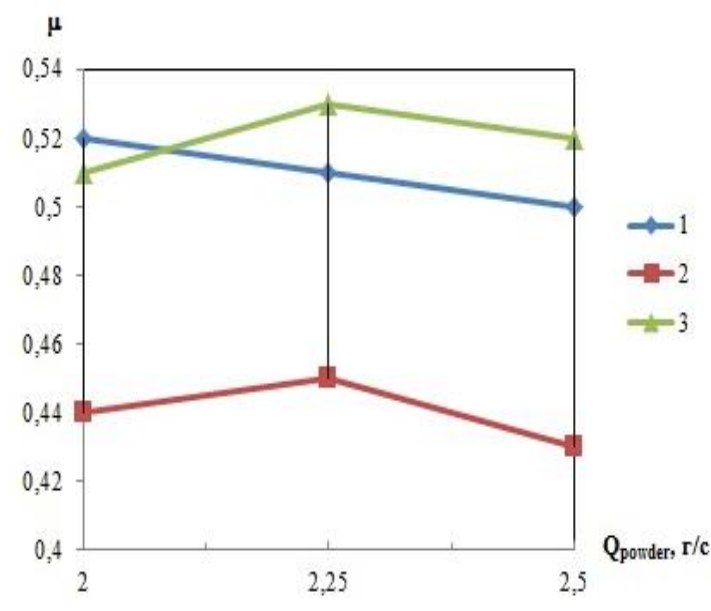

$\mathbf{a}$

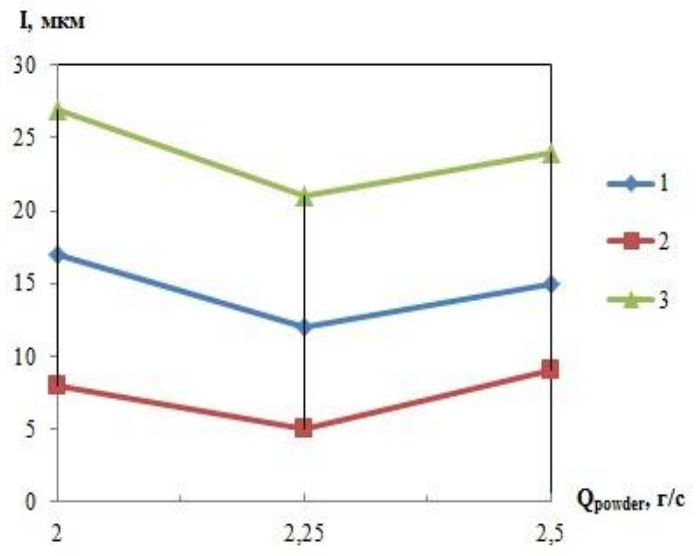

b

Fig. 4. Dependence of wear rate (a) and the friction coefficient (b) on the supply of powder into the HVAF flow at the values of the powder supply:

$$
\begin{aligned}
& 1-20 \mathrm{~g} / \mathrm{s} ; \\
& 2-30 \mathrm{~g} / \mathrm{s} ; \\
& 3-40 \mathrm{~g} / \mathrm{s}
\end{aligned}
$$


Optical (Fig. 5) and electron microscopy (Fig. 6, 7) has been studied to explain the obtained results of the friction surface.

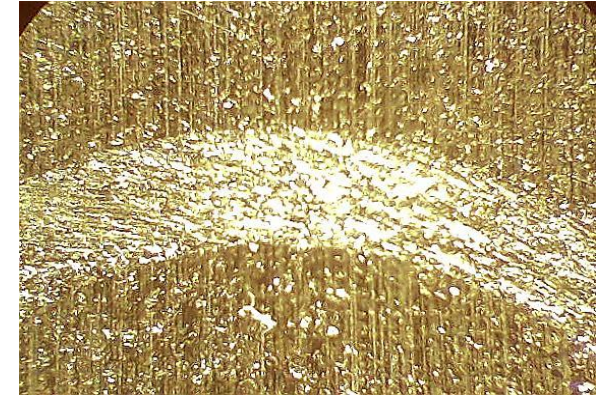

a

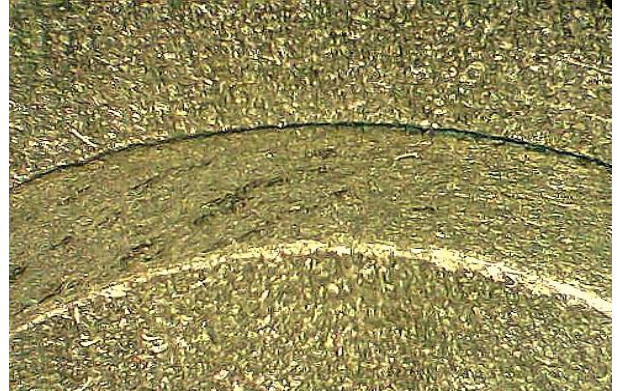

b

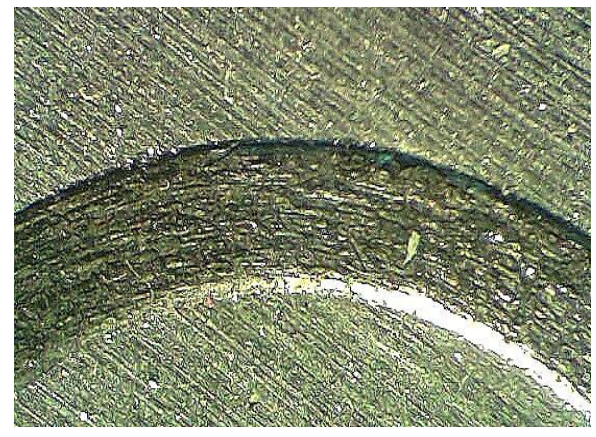

Fig. 5. Photographs of the friction surfaces of the samples (pressure $30 \mathrm{MPa}$, oscillation frequency $30 \mathrm{~Hz}$, amplitude $10 \mathrm{mkm}, 0.5$ megacycles), powder consumption $2.25 \mathrm{~g} / \mathrm{s}$, at the expense of fuel-air mixture for magnification 50 : $\mathrm{a}-\mathbf{3 0} \mathrm{g} / \mathrm{s}$; $\mathrm{b}-\mathbf{4 0} \mathrm{g} / \mathrm{s}$;

c - without coating

The general view of the friction surfaces at magnification 50 is obtained on a laser scanning microscope LSM, which has a digital processing of the surface relief and automatically calculates the amount of wear according to the previously described method. It also allows you to get high-quality images for visual analysis of friction surfaces with an optimal powder consumption of $2.25 \mathrm{~g} / \mathrm{s}$ (Fig. 5).

Analyzing these images, we can draw the following conclusions. Fig. 5, a shows the friction path of the coating, which was obtained at the expense of the fuel-and- air mixture consumption $20 \mathrm{~g} / \mathrm{s}$, since it has a porosity of $7 \%$, it revealed a wear rate of $12 \mathrm{mkm}$, and the friction coefficient of 0.51 . Figure 5 , b shows the friction path of the coating obtained at the fuel-and-air mixture consumption of $30 \mathrm{~g} / \mathrm{s}$, as it has a porosity of $1-2 \%$, which revealed a wear rate of $5 \mathrm{mkm}$ and a friction coefficient of 0.45 . The friction path of the coating obtained at the fuel-and-air mixture consumption $40 \mathrm{~g} / \mathrm{s}$, as it has a porosity of $3 \%$ is shown in Figure 5 , c. It showed a wear rate of $21 \mu \mathrm{m}$ and a friction coefficient of 0.53 . For comparison, a sample of uncoated steel 45 showed a wear rate of $50-60 \mathrm{mkm}$ (Fig. 5, d).

In order to explain the high wear resistance of the friction path, the coating obtained by modes of fueland-air mixture consumption $30 \mathrm{~g} / \mathrm{s}$ and powder $2.25 \mathrm{~g} / \mathrm{s}$ has been investigated by an electron microscope using micro spectroscopic analysis of the elemental composition of the characteristic sections, the results of which are shown in Fig. 6 and micro-X-ray spectral analysis of the elemental composition in the direction of an arbitrary line drawn through the friction path, the results of which are shown in Fig. 7.

So, Fig. 6 spectrum 3 indicates an increase in oxygen concentration to $35.72 \%$ in the friction surface compared to spectrum 2 , where the oxygen concentration is insignificant $0.11 \%$ by weight. Also, $0.34 \%$ of iron was found in the friction surface, which was probably transferred from the counterface to the friction surface.

Also, the surface of the friction coating is saturated with carbon up to $1.60 \%$ by weight, which is probably not in a free state, as it would significantly reduce the friction coefficient for the coating of this composition. All results in weight $\%$.

The results of micro-X-ray spectral analysis of the elemental composition in the direction of an arbitrary line drawn through the friction path (yellow) are shown in Fig. 7, a. Also in this drawing nickel is shown in the red color, the aluminum is shown in green, and oxygen is blue on the surface being investigated. 


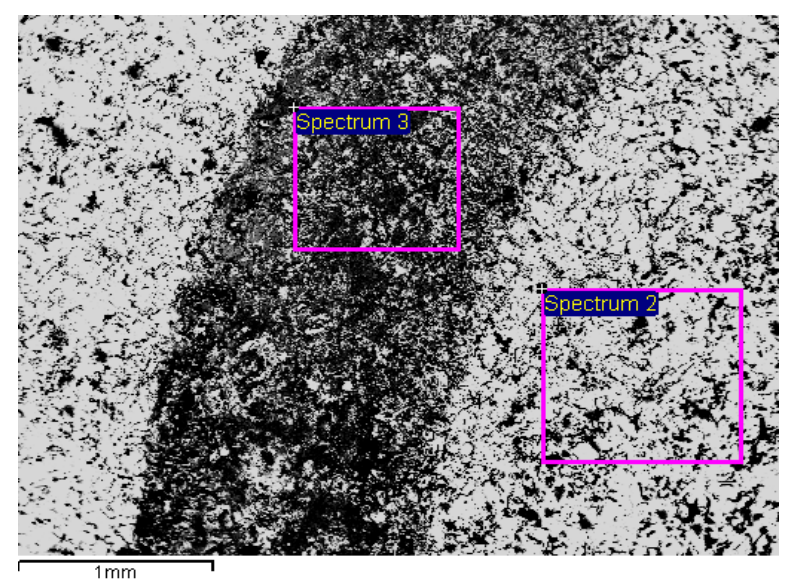

Fig. 6. Structure of the friction path of HVAF-coating on steel 45 in the application mode:

fuel mixture consumption of $30 \mathrm{~g} / \mathrm{s}$, powder consumption of $2.0 \mathrm{~g} / \mathrm{s}$. $\mathrm{X}$-ray spectrum analysis results in Tab. 2

Let us carefully analyze the magnified images of the distribution of chemical elements on the surface of the coating friction (Fig. 7, b, c, d). As it can be seen in the friction path, the concentration of nickel is significantly reduced (Fig. 7, b), it means there is "lack" in the friction area, it may be due to its transfer to the surface of the counterface and dissolution in the steel substrate. The spectra of aluminum and oxygen (Fig. 7, c, d) coincide, indicating the oxidation of aluminum and the formation of friction of aluminum oxide on the surface. The fact that nickel friction does not oxidize will have a positive effect on the corrosion resistance of the coating, which will be positive for locking latches of two-section self-propelled passenger stairs.

Table 2

X-ray spectrum analysis results for Fig. 6

\begin{tabular}{|c|c|c|c|c|c|c|}
\hline Spectra & $\mathrm{O}$ & $\mathrm{Fe}$ & $\mathrm{C}$ & $\mathrm{Al}$ & $\mathrm{Ni}$ & Total \\
\hline Spectrum 2 & 0,11 & 0,34 & - & 17,25 & 82,29 & 100 \\
\hline Spectrum 3 & 35,72 & 0,23 & 1,60 & 6,33 & 56,12 & 100 \\
\hline Max. & 35,72 & 0,34 & 1,60 & 17,25 & 82,29 & - \\
\hline Min. & 0,11 & 0,23 & 0 & 6,33 & 56,12 & - \\
\hline
\end{tabular}

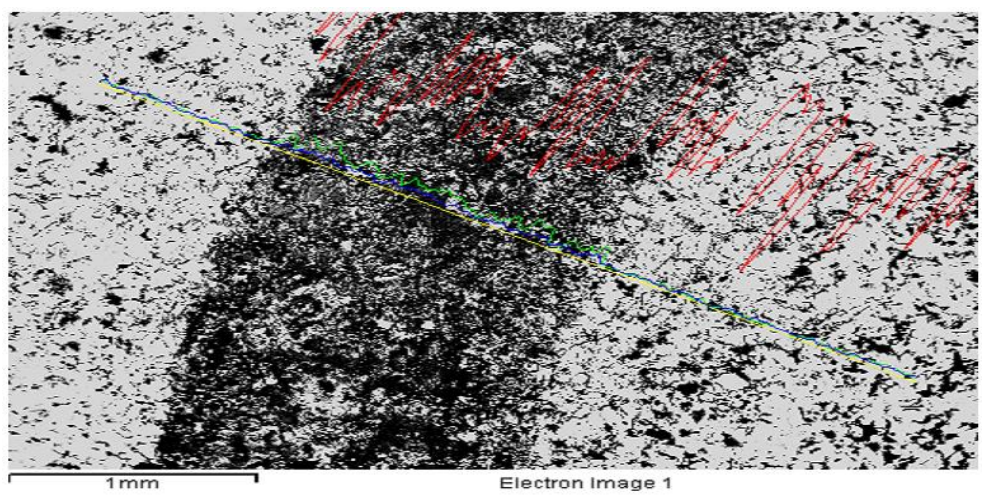

$\mathbf{a}$

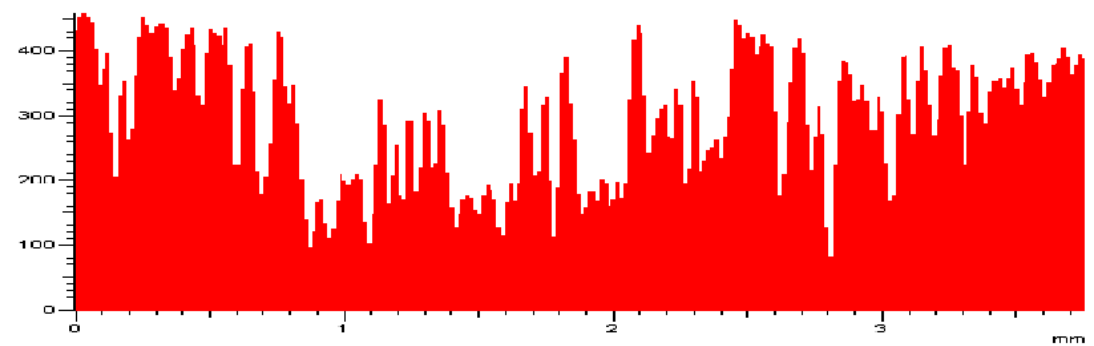



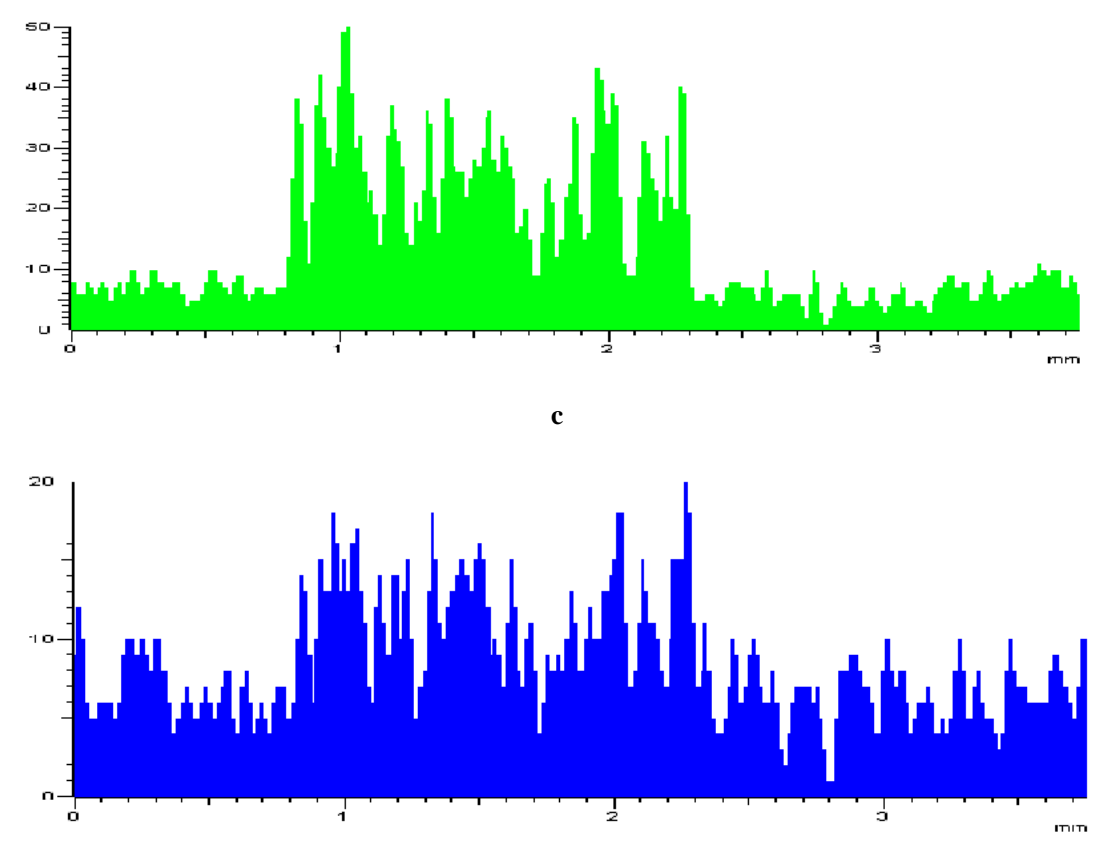

d

Fig. 7. The distribution of chemical elements in the friction path of the HVAF-coating of intermetallics $\mathrm{Ni}_{3} \mathrm{Al}$ on the surface of $\mathrm{St45}$ for a magnification of 100 :

$$
\begin{gathered}
\text { a-electron photo; } \\
\text { b-nickel; } \\
\text { c-aluminum; } \\
\text { g-oxygen }
\end{gathered}
$$

Such mechanism of wear is described in the work of B.I. Kosteckyi, it is of oxidative type and is favorable in terms of wear resistance of friction couple.

Thus, as a result of the HVAF-coating synthesis and testing it for durability in conditions close to the work of future products, its technological features have been determined, which intensify its oxidative wear mechanism and are optimal for its surface strength. The optimization of the modes of application of HVAFcoatings with respect to their wear resistance is of great scientific interest, which requires a full-factorial planning of the experiment and making a polynomial model of the given response functions.

\section{Conclusions}

1. In the case of tribotechnical tests of the developed coatings in fretting corrosion under conditions simulating the operation of locking latches of two-section passenger stairs, it has been found that under the modes: for oscillation frequencies of $30 \mathrm{~Hz}$, which corresponds to the average frequencies of rotation of the base engine at crankshaft rotation $1800 \mathrm{~min}$ in accordance with the rated mode of operation of the engine and loads of $1500 \mathrm{~N}$, which corresponds to the load on the contact friction area in $30 \mathrm{MPa}$, the coating showed the intensity of wear in the range of $5-25 \mathrm{mkm}$, and the coefficients of friction were of $0,43-0,54$, indicating that the coating is in frictional range. Therefore, the developed coating will work well in the range of all operating modes of locking latches two-section passenger stairs with the selected composition which is corrosion-resistant and the products of corrosion will not distort the friction zone.

2. The microscopic study of the wear mechanisms of the developed coatings allows to state that it is the intermetallic reinforcing phase that has good adhesion to the basic elements of steel, which is crucial in the wear resistance of coatings. And the wear mechanism of the developed coatings is close to oxidizing.

\section{References}

1. EN 1915-1:2001+A1:2009: Aircraft ground support equipment - General requirements - Part 1: Basic safety requirements - CEN: 2009, -47 p.

2. EN 1915-2:2001+A1:2009:, Aircraft ground support equipment — General requirements — Part 2: Stability and strength requirements, calculations and test methods - CEN: 2009, $-30 \mathrm{p}$.

3. AD Panasyuk, AP Umansky, AG Dovgal Investigation of the contact interaction of SiC-Al2O3 ceramics with nickel, aluminum and nickel-aluminum alloys // Melt adhesion and soldering of materials. No. 43, 2010 With 55-63.

4. А. П. Уманский, А. Г. Довгаль Разработка металлокерамических материалов и покрытий на основании системы $\mathrm{SiC}-\mathrm{Al} 2 \mathrm{O} 3$ для торцевых уплотнений центробежных насосов технологического обо- 
рудования аэропортов. // Матеріали Х міжнародної науково-технічної конференції «АВІА-2011», - том. 2. - K.: 2011, - C. 13.5-13.8.

5. Konoval VP, Dovgal AG, Umansky AP, Panasyuk AD, Subbotin VI (Ti, Cr) B2 - NiAl composite materials with different ratio of structural components for coating // Proceedings of the III International Samsonov Conference "Material Science of Refractory Compounds". K .: 2012. p. 168.

6. Коновал В. П., Пугачевська С. П., Довгаль А. Г. Контактна взаємодія матеріалів на основі дибориду титану-хрому із сполуками на основі нікелю. // Матеріали II конференції молодих учених «Реальність та перспективи матеріалознавства», 21-25 червня 2011 року., К.: 2011, - С. 50-51.

7. Уманский А. П., Полярус Е. Н., Украинец М. С., Довгаль А. Г., Капитанчук Л. М., Субботин В. И. Исследование структуры и свойств композиционных материалов и покрытий из них на основе системы NiAl-TiB2 // Авиационно-космическая техника и технология. - № 10 (107). - 2013. - С. $20-24$.

8. Дмитриченко М.Ф., Приймак Л.Б., Довгаль А.Г., Білякович О.М., Савчук А.М., Туриця Ю.О. Вибір складу підшару для термобар'єрних покриттів теплонавантажених деталей авіаційної наземної техніки. // Проблеми трибології. - № 3. - 2017. - С. 69-75.

9. Dovgal AG, Vronskaya OS, Kostenko AD Development of gas-thermal carbide-silicon coatings with increased level of wear resistance // Problems of tribology. - № 4. - 2013. - P. 33-39.

10. A. P. Umanskii, A. G. Dovgal', V. M. Kisel', and Yu. I. Evdokimenko Structure and Wear Regularities of Coatings from Composite Metal-Ceramic Materials of the SiC-Al2O3-Ni-Al System // Journal of Superhard Materials. - 2012. - Vol. 34. - No. 2. - pp. 110-117.

11. L. Pryimak, A. Dovgal, Ye. Puhachevska Analysis of Structure and Tribitechnical Properties of Plasma Carbide-Silicon Coatings Under Conditions of Elevated Temperatures // Eastern-European Journal of Enterprise Technologies. - Volume 1/5 (85). - 2017. - P. 46-53.

Довгаль А.Г., Приймак Л.Б., Трофімов І.Л. Визначення зносостійкості та механізмів зносу HVAF покриттів на основі складу $\mathrm{Ni}-\mathrm{Al}$ залежно від технологічних режимів їх нанесення.

Описані дослідження відносяться до авіаційної та машинобудівної галузей. Світовий досвіт експлуатації авіаційної техніки накопичив величезний статистичний матеріал по відмовам бортових систем та наземної техніки через підвищений рівень зношування деталей. Саме тому питання відносно дослідження і поліпшення протизносних властивостей деталей авіаційної техніки є одним із складових при розгляді пріоритетних напрямів забезпечення надійності роботи моторної техніки і вузлів тертя. Покриття $\mathrm{Ni}_{3} \mathrm{Al}$ було нанесено на середньо вуглецеву сталь методом високошвидкісного повітряно-паливного напилення. Встановлено високий ефект такого способу нанесення покриттів та виявлено різні хімічні явища. На електронному мікроскопі досліджено структуру отриманого покриття. Отримане покриття було випробувано на парі тертя, що моделювала фретінг процес, який відбувається в парі фіксуючих пристроїв самохідних пасажирських трапів. Встановлено, що покриття також має захист від корозії. Поверхні тертя досліджували на електронному мікроскопі. Встановлено механізми зносу та оптимальні режими нанесення покриття HVAF з точки зору опору зносу.

Ключові слова: зношування, зносостійкість, покриття, адгезія, осадження покриття, повітрянопаливне напилення високої вологості (HVAF). 